\title{
Association between sociodemographic characteristics and depressive symptoms in hospitalized elderly
}

\author{
Associação entre características sociodemográficas e sintomas depressivos em idosos \\ hospitalizados
}

Isabela Maria Tavares do Nascimento ${ }^{1}$, Paulo Filipe $\mathrm{Mello}^{2}$, Alcimar Marcelo do Couto ${ }^{1}$, Gilberto de Lima Guimarães ${ }^{1}$, Isabel Yovana Quispe Mendoza ${ }^{1}$

\begin{abstract}
Objective: to describe the sociodemographic characteristics associated with depressive symptoms in hospitalized elderly. Methods: cross-sectional study carried out in a public teaching hospital. The sample was composed of 96 individuals aged $\geq 60$ years, hospitalized in a clinical and surgical unit. The data collection was performed through a semi-structured interview with the instrument Geriatric Depression Scale. The variables were described through frequencies, percentages, means and standard deviations. The Fisher's exact test was used to assess the association with depressive symptoms. Results: a total of $45.8 \%$ of the elderly presented mild to moderate depressive symptoms and $1.0 \%$ had severe symptoms. There was a predominance of women, between 60 and 79 years old, living with a partner, with low level of education (one to seven years of schooling), Catholics, retirees or pensioners, and with a family income of up to three minimum wages. Conclusion: the labor situation presented a statistically significant association with depressive symptoms in the hospitalized elderly.
\end{abstract}

Descriptors: Depression; Aged; Hospitals, General.

Objetivo: descrever as características sociodemográficas associadas a sintomas depressivos em idosos hospitalizados. Métodos: estudo transversal realizado em hospital público de ensino. Amostra de 96 indivíduos com idade $\geq 60$ anos, internados em unidade clínica e cirúrgica. A coleta de dados foi realizada por meio de entrevista semiestruturada com o instrumento Geriatric Depression Scale. As variáveis foram descritas por frequências, porcentagem, média e desvio padrão. Para avaliar a associação com os sintomas depressivos foi utilizado o teste Exato de Fisher. Resultados: $45,8 \%$ dos idosos apresentaram sintomas depressivos leves a moderados e 1,0\% sintomas graves. Houve predominância de mulheres, idade entre 60 e 79 anos, com companheiro, baixa escolaridade (um a sete anos de estudo), religião católica, aposentados ou pensionistas e renda familiar de até três salários mínimos. Conclusão: a situação trabalhista apresentou associação estatisticamente significante com sintomas depressivos em idosos hospitalizados.

Descritores: Depressão; Idoso; Hospitais Gerais.

\footnotetext{
${ }^{1}$ Universidade Federal de Minas Gerais. Belo Horizonte, MG, Brazil.

${ }^{2}$ Universidade Federal dos Vales do Jequitinhonha e Mucuri, Diamantina, MG, Brazil. 


\section{Introduction}

The prevalence of depressive symptoms in the general population varies from 5 to $11.0 \%$, being higher among women. This prevalence increases to $30.0 \%$ in the elderly. In this group, depression is one of the most frequent chronic diseases that increases the possibility of developing functional incapacity, increased financial expenses, poor quality of life, and the use of health services, and can lead to the most severe outcome of the disease, i.e. suicide ${ }^{(1-4)}$.

Previous studies aimed at identifying the association between sociodemographic characteristics and depressive symptoms have shown that women are more susceptible to depression due to social isolation and deprivation of family relationships. Moreover, low schooling and illiteracy have been recognized as factors consistently associated with depressive symptoms. Living with the spouse or having a partner can be considered a psychosocial protective factor. Regarding health conditions, the prevalence of depression has been reported as non-related to coronary heart disease, heart failure and stroke in the elderly ${ }^{(2-5)}$. As for religion, a study carried out with elderly people in the Family Health Strategy identified that high scores in the religiosity index were not related to depressive symptoms $^{(5)}$.

The presence of comorbidities and polypharmacy, common among the elderly, makes the diagnosis and appropriate treatment of depression become a complex process. Moreover, depression is often overlooked in hospitalized elderly because health professionals associate depressive symptoms with normal manifestations of senescence. However, the presence of this disorder may lead to loss of autonomy and, consequently, worsening of the clinical picture ${ }^{(6)}$.

In this way, the nursing evaluation should overcome the limits of conventional approaches with a merely curative goal, but should rather be able to recognize the subject in his entirety and identify early signs and symptoms of depression. Such an attitude will aid the preparation of an adequate plan of care, reducing clinical complications in the short and long term $^{(7)}$.

Despite the high prevalence of depression, the disease is often undiagnosed and undetected. The presence of diseases associated with the difficulty of diagnosis is a condition that leads to increased morbidity and mortality in the elderly. Therefore, the screening of depressive symptoms and knowledge of the associated factors are fundamental for the planning of nursing care, which can make it possible to provide comprehensive and multidimensional assistance to the elderly in the hospital context.

In view of the above, the purpose of this study was to describe the sociodemographic characteristics associated with depressive symptoms in hospitalized elderly.

\section{Methods}

This is a cross-sectional study carried out with elderly patients admitted to a public teaching hospital in the city of Belo Horizonte, Minas Gerais, Brazil, between May and July 2016. The institution provides care for clinical/surgical urgencies and trauma.

Patients with the following characteristics were included: age $\geq 60$ years; hospitalized in the medical and surgical clinics; with score $\geq 13$ in the cognitive evaluation through the Mini Mental State Examination in the case of illiterates, $\geq 18$ in the case of low and medium schooling, and $\geq 26$ in the case of high schoo$\operatorname{ling}^{(8)}$. Patients with the following characteristics were excluded: cognitive deficit according to the evaluation of the Mini Mental State Examination (86); patients with a previous diagnosis of dementia (25); absent from the bed (33); with difficulty of communication, either due to aphasia (44) or delirium (9). The sample resulted in 96 elderly subjects, who were allocated for convenience.

The data collection was divided into two stages: (1) active search in the institution's clinical/surgical inpatient units for which the list of inpatients provided by the technology and information techno- 
logy sector was used, and collection of data in a form with (a) sociodemographic variables (such as: age, sex, schooling, income, social network and religion) and (b) main medical diagnosis and comorbidities; (2) semi-structured interview with application of the instrument Geriatric Depression Scale.

The Geriatric Depression Scale is a short version of the original scale, adjusted for the geriatric population in the Portuguese language, and widely used today in Brazil and the world to identify depressive symptoms in the elderly. The scale has 15 affirmative and negative questions, which can be scored from zero to 15 points. In this study, the cut-off of $\geq 6$ points was considered as an indicative of the presence of depressive symptoms, based on previous studies that adopted the same strategy ${ }^{(9)}$.

The data were processed and analyzed in the Stata software, version 13.0. The descriptive analysis characterized the population studied by frequencies, percentages, means and standard deviations. The Fisher's exact test was used to assess the association with depressive symptoms. The level of significance adopted was $\mathrm{p}=0.05$.

The study complied with the formal requirements set by national and international regulatory standards for research involving human beings.

\section{Results}

The characterization of the participants showed that $53.2 \%$ of the elderly did not present depressive symptoms and $45.8 \%$ presented them. Among those with depressive symptoms, $45.8 \%$ had symptoms classified as mild to moderate and only $1.0 \%$ as severe (Table 1).

Table 2 describes the sociodemographic characteristics of the hospitalized elderly. There was a predominance of females (54.2\%); aged 60-79 years (74.0\%); with a partner (51.1\%); with schooling between 1 and 7 years (75.5\%); retirees and pensioners (80.2\%); with family income between 1 and 3 minimum wages (92.7\%); having the family members as social network (82.3\%); practitioners of the Catholic faith (69.8\%); and living with the spouse (49.0\%).

With regard to the possible influent factors in the depression of the hospitalized elderly, the Fisher's Exact test showed an association between depressive symptoms and the labor situation $(\mathrm{p}=0.01)$, as shown in Table 2.

Table 1 - Distribution of the responses of the interviewed elderly according to the Geriatric Depression Scale and descriptive statistics

\begin{tabular}{lcc}
\hline Geriatric Depression Scale 15 & n (\%) & Mean (SD) \\
\hline No depressive symptoms 0-5 & $51(53.2)$ & $5.4(3.1)$ \\
With depressive symptoms $\geq 6-11$ & $44(45.8)$ & \\
Severe depression $\geq 11-15$ & $1(1.0)$ & \\
Total & $96(100.0)$ & \\
\hline
\end{tabular}

Table 2 - Frequency of sociodemographic variables of the hospitalized elderly, according to the Geriatric Depression Scale

\begin{tabular}{|c|c|c|c|c|}
\hline Variables & $\begin{array}{r}\begin{array}{c}\text { Without } \\
\text { depressive } \\
\text { symptoms }\end{array} \\
\mathrm{n}(\%)\end{array}$ & $\begin{array}{c}\text { With } \\
\text { depressive } \\
\text { symptoms } \\
\mathrm{n}(\%) \\
\end{array}$ & n (\%) & $\mathbf{p}^{*}$ \\
\hline \multicolumn{5}{|l|}{ Sex } \\
\hline Female & $24(25.0)$ & $28(29.2)$ & $52(54.2)$ & \multirow[t]{2}{*}{0.211} \\
\hline Male & $27(28.1)$ & $17(17.7)$ & $44(45.8)$ & \\
\hline \multicolumn{5}{|l|}{ Age (years) } \\
\hline $60-79$ & $41(42.6)$ & $30(31.2)$ & $71(73.8)$ & \multirow[t]{2}{*}{0.185} \\
\hline$>80$ & $10(10.4)$ & $15(15.6)$ & $25(26.0)$ & \\
\hline \multicolumn{5}{|l|}{ Marital status } \\
\hline Without partner & $22(22.9)$ & $25(26.0)$ & $47(48.9)$ & \multirow[t]{2}{*}{0.175} \\
\hline \multirow{2}{*}{\multicolumn{5}{|c|}{ Schooling (years) }} \\
\hline & & & & \\
\hline 0 & $7(7.3)$ & $10(10.4)$ & $17(17.7)$ & \multirow[t]{3}{*}{0.452} \\
\hline 1 to 7 & $42(43.7)$ & $31(31.8)$ & $73(76.0)$ & \\
\hline$\geq 8$ & $2(2.0)$ & $4(4.2)$ & $6(6.3)$ & \\
\hline \multicolumn{5}{|l|}{ Labor situation } \\
\hline Employed & $9(9.4)$ & - & $9(9.4)$ & \multirow[t]{3}{*}{$0.013^{*}$} \\
\hline Unemployed & $4(4.2)$ & $6(6.3)$ & $10(10.4)$ & \\
\hline Retiree/Pensioner & $38(39.6)$ & $39(40.6)$ & $77(80.2)$ & \\
\hline \multicolumn{5}{|c|}{ Family income (minimum wages) } \\
\hline Up to 3 & $49(51.0)$ & $44(45.8)$ & $93(96.8)$ & \multirow[t]{2}{*}{0.533} \\
\hline$>3$ & $2(2.0)$ & $1(1.0)$ & $3(3.0)$ & \\
\hline \multicolumn{5}{|l|}{ Social network } \\
\hline Friends & $2(2.0)$ & $3(3.1)$ & $5(5.2)$ & \multirow[t]{4}{*}{0.722} \\
\hline Neighbors & $4(4.2)$ & $3(3.1)$ & $7(7.3)$ & \\
\hline Family members & $41(42.7)$ & $38(39.5)$ & $79(82.2)$ & \\
\hline Health services & $4(4.2)$ & $1(1.0)$ & $5(5.2)$ & \\
\hline \multicolumn{5}{|l|}{ Religion } \\
\hline Catholic & $33(34.4)$ & $34(35.4)$ & $67(69.8)$ & \multirow[t]{3}{*}{0.162} \\
\hline Evangelical & $16(16.7)$ & $10(10.4)$ & $26(27.1)$ & \\
\hline Others & $2(2.0)$ & $1(1.0)$ & $3(3.0)$ & \\
\hline \multicolumn{5}{|l|}{ Living } \\
\hline Alone & $8(8.3)$ & $6(6.2)$ & $14(14.5)$ & \multirow[t]{6}{*}{0.084} \\
\hline With the spouse & $28(29.2)$ & $19(19.8)$ & $47(49.0)$ & \\
\hline Long-stay institution & $2(2.0)$ & $3(3.1)$ & $5(5.1)$ & \\
\hline With siblings & - & - & - & \\
\hline With children & $2(2.0)$ & - & $2(2.0)$ & \\
\hline With grandchildren & $9(9.4)$ & $17(17.7)$ & $26(27.1)$ & \\
\hline
\end{tabular}




\section{Discussion}

The study presented limitations regarding the convenience sample, which is not representative of the hospitalized elderly population, reducing the possibility of finding more conclusive results. Because the study had a cross-sectional design, it was not possible to know the cause-and-effect relationship. Moreover, other variables such as hospitalization time, comorbidities and self-perception of health were not investigated.

In order to associate depressive symptoms with sociodemographic characteristics, it was necessary to know the prevalence of these symptoms in the subjects who participated in the study. Thus, the presence of mild to moderate depressive symptoms was similar to that found in the national literature, which shows a prevalence of 46.0 to $56.1 \%$ of the elderly hospitalized in general hospitals and of $36.5 \%$ in elderly patients hospitalized in emergency services ${ }^{(10-12)}$.

Depression in hospitalized elderly may be associated with the fact of being away from home and subjected to the routine of the institution, which can generate feelings of fear and distress. In addition, the situation of sickness, that is, the weakening of health status, can be considered as a factor that predisposes to depression ${ }^{(10-12)}$.

The study found no significant association between depressive symptoms and sex. This finding is corroborated by the results of a research carried out with elderly patients admitted to emergency services. The non-significant difference between sexes may be related to the fact that, being ill and also hospitalized is considered a hardship for all people, regardless of $\operatorname{sex}^{(10)}$.

Elderly patients aged between 60 and 79 presented higher percentages of depressive symptoms when compared to those aged more than 80 years. These results were similar to a study carried out with hospitalized patients with type 2 diabetes. For the authors, life stressors are possibly expected and accepted and, therefore, more tolerated by older people. This may explain why depression was found to be less frequent in this age group during the interviews ${ }^{(13)}$.

Elderly with partners are more likely to have depression, although this difference was not statistically significant in the present study. The hospital environment can collaborate to the appearance of feelings of sadness and hopelessness due to the situation in which they are, i.e. the situation of being ill ${ }^{(12,14)}$.

Schooling was not associated with depressive symptoms, but these symptoms were more frequent in the elderly with low schooling. Higher level of education is found in the literature as a factor of resilience or protection, because it increases the coping resources of the elderly in the face of stressful situations and depression, and is directly related to family inco$\mathrm{me}^{(12,14) \text {. }}$

Although this study did not identify an association between family income and depressive symptoms, it is considered that the proportion of elderly people earning less than three minimum wages who presented depressive symptoms was high. The literature highlights that social inequalities influence the life conditions and health status. Thus, people belonging to the lower socioeconomic classes are subject to conditions such as unemployment, underemployment, unstable employment and low income, which predisposes them to a higher risk of developing depressive symptoms. These conditions may hamper the access to health care, leisure and social support ${ }^{(11,15)}$.

Less than half of the elderly with depressive symptoms had the family as their main social network. Depression and anxiety reflect on emotional changes and tend to negatively affect the perception of the available social support and family functioning. On the other hand, the perception about family functioning is related to the evaluation that the elderly make about the quality of their relationships, the degree of effectiveness shown by the family in meeting their ne- 
eds, and the extent to which family relationships correspond to their expectations ${ }^{(16)}$.

In this study, we found a statistically significant association between the labor situation of the elderly and depressive symptoms. Research indicates that lack of a work routine, low income and loss of social status can generate serious damages of a psychic nature. The authors conclude that work occupies a dimension in the existence of the human being, since it is from work that subjects are able to build up their identity and produce meaning to their existence as social beings. Depression in retired elderly may be a result of lack of new perspectives, in the face of ruptures, conclusions or losses. Thus, retirement represents a determining factor for the psychic fragilization of the elderly ${ }^{(17-19)}$.

Most of the interviewed elderly reported to belong to the Catholic religion, and of these, $35.0 \%$ presented depressive symptoms. This fact may be related to the greater number of individuals belonging to Catholicism in Brazil. According to the latest census, there are 123 million Catholics in Brazil, representing $64.6 \%$ of the population. Illness, physical symptoms, invasive procedures, dependence, change of routine and of social roles, distance from family members, the severity of the health problem, fear of the unknown and fantasies about death are situations often experienced by the elderly during hospitalization. Religion is a resource that helps to cope with these events, because it promotes optimism and hope about the improvement of the health status ${ }^{(20)}$.

Less than one-third of the elderly living with their spouses had depressive symptoms. Similar results were found in a study carried out with elderly people enrolled in the Family Health Strategy in which a negative relation between depression and widowhood was identified. The results of both studies are divergent from those found in the literature, since having a partner has been considered a psychosocial protective factor, promoting mutual support and coping with adverse situations ${ }^{(2-5)}$.
The high prevalence of depression in the elderly requires special attention because of the impact of this disease on the health of the individuals. Therefore, depressive symptoms in this age group in the hospital context should be routinely investigated. Nurses who deal with older people should be attentive and prepared not only to recognize depressive symptoms but to extend their assessment to other dimensions such as psychic, social and spiritual. Interdisciplinary interventions result in greater solving power, from the detection of depressive symptoms, diagnosis of depression, and counter-reference to Primary Health Care so as to favor effective hospital discharge of the elderly ${ }^{(3,17)}$.

Knowing the association between the labor situation of the elderly and depressive symptoms is a finding that can support the planning of actions aimed at family life, affective life, leisure, participation in the community, and stimulation of paid or voluntary work activities. These activities can constitute important elements in the reaffirmation of the personal, professional and social identity of the elderly.

\section{Conclusion}

The labor situation presented a statistically significant association with depressive symptoms in hospitalized elderly.

\section{Collaborations}

Nascimento IMT and Mello PF contributed to the drafting and design of the study, analysis and interpretation of data and writing of the article. Couto AM contributed to the writing of the article. Guimarães GL contributed to the writing of the article, relevant critical review of intellectual content and final approval of the version to be published. Mendoza IYQ contributed to the drafting and design of the study, analysis and interpretation of data, writing of the article and final approval of the version to be published. 


\section{References}

1. Silva MT, Galvão TF, Martins SS, Pereira MG. Prevalence of depression morbidity among Brazilian adults: a systematic review and metaanalysis. Rev Bras Psiquiatr. 2014; 36(3):26270. doi: http://dx.doi.org/10.1590/1516-44462013-1294

2. Silva AR, Sgnaolin V, Nogueira EL, Loureiro F, Engroff P, Gomes I. Non-communicable chronic diseases and sociodemographic associated with symptoms of depression in elderly. J Bras Psiquiatr. 2017; 66(1):45-51. doi: http://dx.doi. org/10.1590/0047-2085000000149

3. Castro-de-Araujo LF, Barcelos-Ferreira R, Martins CB, Bottino CM. Depressive morbidity among elderly individuals who are hospitalized, reside at long-term care facilities, and are under outpatient care in Brazil: a meta-analysis. Rev Bras Psiquiatr. 2013; 35(2):201-7. doi: http:// dx.doi.org/10.1590/1516-4446-2012-0905

4. Nogueira EL, Rubin LL, Giacobbo SS, Gomes I, Cataldo Neto A. Screening for depressive symptoms in older adults in the Family Health Strategy, Porto Alegre, Brazil. Rev Saúde Pública. 2014; 48(3):368-77. doi: http://dx.doi. org/10.1590/S0034-8910.2014048004660

5. Figueiredo MLF. Depressive symptoms in elderly women: knowing them to care for [Editorial]. Rev Rene. 2017; 18(2):147. doi: http://dx.doi. org/10.15253/2175-6783.2017000200001

6. Chaves ECL, Paulino CF, Souza VHS, Mesquita AC, Carvalho FS, Nogueira DA. Quality of life, depressive symptoms and religiosity in elderly adults: a cross-sectional study. Texto Contexto Enferm. 2014; 23(3):648-55. doi: http://dx.doi. org/10.1590/0104-07072014001000013

7. Ferrari AJ, Somerville AJ, Baxter AJ, Norman $R$, Patten SB, Vos $T$, et al. Global variation in the prevalence and incidence of major depressive disorder: a systematic review of the epidemiological literature. Psychol Med. 2013; 43:471-81. doi: http://dx.doi.org/10.1017/ S0033291712001511
8. Bertolucci PHF, Brucki SMD, Campacci SR, Juliano Y. O Mini-exame do estado mental em uma população geral: Impacto da escolaridade. Arq Neuropsiquiatr [Internet]. 1994 [citado 2017 ago 12]; 52(1):1-7. Disponível em: http://www.scielo. $\mathrm{br} / \mathrm{pdf} / \mathrm{anp} / \mathrm{v} 52 \mathrm{n} 1 / 01 . \mathrm{pdf}$

9. Almeida OP, Almeida AS. Confiabilidade da versão brasileira da Escala de Depressão em Geriatria (GDS) versão reduzida. Arq Neuropsiquiatr [Internet]. 1999 [citado 2017 jul 15]; 57(2B):4216. Disponível em: http://www.scielo.br/pdf/anp/ v57n2B/1446.pdf

10. Cohen R, Paskulin LMG, Prieb RGG. Prevalência de sintomas depressivos entre idosos em um serviço de emergência. Rev Bras Geriatr Gerontol. 2015; 18(2):307-17. doi: http://dx.doi. org/10.1590/1809-9823.2015.14052

11. Borges LJ, Benedetti TRB, Xavier AJ, D’Orsi E. Associated factors of depressive symptoms in the elderly: Epi Floripa Study. Rev Saúde Pública. 2013; 47(4):701-10. doi: http://dx.doi. org/10.1590/S0034-8910.2013047003844

12. Nunes WA, Dias FA, Nascimento JS, Gomes NC, Tavares DMS. Cognition, functionality and depression indicative among elderly. Rev Rene. 2016; 17(1):103-11. doi: http://dx.doi. org/10.15253/2175-6783.2016000100014

13. Dennis M, Kadri A, Coffey J. Depression in older people in the general hospital: systematic review of screening instruments. Age Ageing. 2012; 41(2):148-54. doi: http://dx.doi.org/10.1093/ ageing/afr169

14. Nobrega IRAP, Leal MCC, Marques APO, Vieira JCM. Fatores associados à depressão em idosos institucionalizados: revisão integrativa. Saúde Debate. 2015; 39(105):536-50. doi: http://dx.doi. org/10.1590/0103-110420151050002020

15. Ferreira VMP, Silva LN, Furuya RK, Schimidt A, Rossi LA, Dantas RAS. Self-care, sense of coherence and depression in patients hospitalized for decompensated heart failure. Rev Esc Enferm USP. 2015; 49(3):388-94. doi: http://dx.doi. org/10.1590/S0080-623420150000300005 
16. Lopes-de-Andrés A, Jiménez-Trujillo MI, Hermández-Barrera V, Miguel-Yanes JM, MéndezBailón M, Perez-Farinos $\mathrm{N}$, et al. Trends in the Prevalence of Depression in Hospitalized Patients with Type 2 Diabetes in Spain: Analysis of Hospital Discharge Data from 2001 to 2011. PLoS One. 2015; 10(2):1-15. doi: http://dx.doi. org/10.1371/journal.pone.0117346

17. Rabelo DF, Neri AL. Avaliação das Relações Familiares por Idosos com Diferentes Condições Sociodemograficas e de Saúde. Psico-USF. 2016; 23(3):90-101. doi: http://dx.doi. org/10.1590/1413-82712016210318

18. Lee H, Lee JA, Brar JS, Rush EB, Jolley CJ. Physical activity and depressive symptoms in older adults. Geriatr Nurs. 2014; 35(1):37-41. doi: http:// dx.doi.org/10.1016/j.gerinurse.2013.09.005
19. Both TL, Kujawa DR, Wobeto MI, Savaris V. Consideração sobre o idoso aposentado: uma intervenção da terapia cognitivo-comportamental como instrumento de preparação à aposentadoria. Rev Bras Ciênc Envelhecimento Hum. 2012; 9(1):90-101. doi: http://dx.doi.org/10.5335/ rbceh.2012.037

20. Reis LA, Menezes TMO. Religiosity and spirituality as resilience strategies among longliving older adults in their daily lives. Rev Bras Enferm. 2017; 70(4):761-6. doi: http://dx.doi. org/10.1590/0034-7167-2016-0630 